\title{
8(b) (1) (A) IIMITATIONS UPON THE RIGHT OF A UNION TO FINE ITS MEMBERS
}

In 1947, shortly after the enactment of the Taft-Hartley amendments to the National Labor Relations Act, Professor Archibald Cox predicted:

The scope and variety of the foregoing problems suggest that Section 8(b) (1) may plunge the [National Labor Relations] Board into a dismal swamp of uncertainty. Its vagueness alone, not to mention the broad interpretations put upon it during the debates in Congress, encourages the filing of great numbers of charges as weapons in fighting the unionization of a plant. A long period of uncertainty and heavy volume of litigation will be necessary before the questions of interpretation can be resolved. ${ }^{1}$

The accuracy of this prophecy was recognized by the court in the recent case of Associated Home Builders of the Greater East Bay, Inc. v. $N L R B,{ }^{2}$ in which the Ninth Circuit was asked to decide whether section 8 (b) (1) (A) ${ }^{3}$ prohibited a union from fining those of its members who exceeded production ceilings set down in the union rules. The court, quoting the above passage, successfully circumvented the issue: "These are matters which are not spelled out in the Act, and we have been unable to find any authoritative decisions which will furnish us answers. . . . Fortunately we find it unnecessary to solve these problems." 5 Notwithstanding the difficulty of the task, the relationship between section 8(b) (1) (A) and union fines must be spelled out by the courts. A sizable body of litigation centering on this question is arising, ${ }^{6}$ and it is evident that some answers will soon begin to appear. The purpose of this Comment is to discover the answer

1 Cox, Some Aspects of the Labor Management Relations Act, 1947, 61 HaRv. L. REv. 1, 33 (1947).

2352 F.2d 745 (9th Cir. 1965).

3 Labor Management Relations Act (Taft-Hartley Act) $\S 8($ b) (1) (A), 61 Stat. 141 (1947), 29 U.S.C. \$158(b) (1) (A) (1964).

4 For the ground upon which the case was decided, see text accompanying note 95 infra.

5 Associated Home Builders of the Greater East Bay, Inc. v. NLRB, 352 F.2d 745, $751 \mathrm{n} .9$ (9th Cir. 1965).

${ }^{6}$ These cases will be discussed in section VIII of this Comment. They include: Local 248, UAW, 149 N.L.R.B. 67 (1964), aff'd sub nom. Allis-Chalmers Mfg. Co. v. NLRB, No. 14853, 7th Cir., Sept. 13, 1965, rev'd on rehearing, 358 F.2d 656 (7th Cir. 1966), cert. granted, 35 U.S.L. WeEK 3110 (U.S. Oct. 10, 1966) (No. 216); Local 138, Int'l Union of Operating Eng'rs, 148 N.L.R.B. 679 (1964); H. B. Roberts, 148 N.L.R.B. 674 (1964), aff'd, 350 F.2d 427 (D.C. Cir. 1965); Local 283, UAW (Wisconsin Motor Corp.), 145 N.L.R.B. 1097 (1964), appeal docketed sab nom. Scofield v. NLRB, No. 14698, 7th Cir., June 24, 1964. 
most consistent with the words of section 8(b) (1) (A) and its purpose (as evidenced by the legislative history); to evaluate the compatibility of this answer with other sections of the statute, other labor legislation and court decisions on analogous problems; to discern the desirability of this answer in light of the burdens it will place on the parties; and finally, to compare this answer with those which the National Labor Relations Board ${ }^{7}$ and the courts are beginning to articulate.

\section{The Scope of the Question}

Section 8(b)(1)(A) states that it shall be an unfair labor practice for a labor organization

to restrain or coerce (A) employees in the exercise of the rights guaranteed in section $7:$ Provided, That this paragraph shall not impair the right of a labor organization to prescribe its own rules with respect to the acquisition or retention of membership therein ...8

It is thus apparent that any inquiry into the effect of section 8 (b) (1) (A) upon the right of a union to fine its members must be limited to fines connected with the exercise of section 7 rights. In the original act, adopted in 1935, these rights of employees included: "the right to self-organization, to form, join, or assist labor organizations, to bargain collectively through representatives of their own choosing, and to engage in other concerted activities for the purpose of collective bargaining or other mutual aid or protection." 9 However, in adding section 8(b) (1) (A) in 1947, Congress also amended section 7 to give employees the correlative right "to refrain from any or all of such [section 7] activities." 10 In considering the relationship between section 8 (b) (1) (A) and union fines, discussion will therefore be limited to those fines which restrict the union member's rights, as an employee, to engage in or refrain from the above activities. Most such fines are imposed because of the member's exercise of the right to refrain from "concerted activities for the purpose of . . . mutual aid or protection." 11 Board."

7 The National Labor Relations Board will hereinafter be referred to as "the

${ }^{8}$ Labor Management Relations Act (Taft-Hartley Act) $\S 8$ (b) (1) (A), 61 Stat. 141 (1947), 29 U.S.C. \&158(b) (1) (A) (1964).

${ }^{9}$ National Labor Relations Act (Wagner Act) §7, 49 Stat. 452 (1935), as amended, 29 U.S.C. \$157 (1964).

10 Labor Management Relations Act (Taft-Hartley Act) \$7, 61 Stat. 140 (1947), 29 U.S.C. \$ 157 (1964). This right to refrain from union activity was restricted by the statute to the extent that a union shop clause (requiring union membership within thirty days of becoming employed) might require the employee to join the union.

11 For example, a union might impose a fine for refusal to join in a strike, to serve on a picket line or to observe union production ceilings. 
Further analysis of the problem will demonstrate that the appropriate inquiry is even narrower in scope, ${ }^{12}$ but, at this point, it is sufficient to state the question at issue as follows: Does a union fine, imposed upon a member-employee for refraining from concerted union activity, "coerce" or "restrain" such member-employee in the exercise of rights guaranteed by section 7 ?

\section{The Text of the Section}

The obvious result of an examination of the text of the section is the observation that fines are nowhere mentioned. It is therefore necessary to proceed to an examination of the objectives or purposes of the section. ${ }^{13}$ Eventually this step leads to a search of the legislative history and closely related sections, but initially it involves an attempt to discern the purpose of the section from the words themselves-in the context of the present problem, does the language of section 8 (b) (1) (A) evince a purpose which would be fulfilled by the inclusion of union fines within its prohibition? To answer this question, careful scrutiny must be given to the words "to restrain or coerce," and to the proviso as to union rules concerning the acquisition and retention of membership.

Although it would not seem to strain the meaning of "coerce" to subsume under it the economic compulsion of a fine, ${ }^{14}$ such an interpretation might be questioned on two grounds. First of all, fines may not have the physical characteristics thought necessary to constitute coercion, i.e., perhaps something akin to physical violence is required. Secondly, fines may not be coercive because, upon becoming union members, employees may implicitly submit themselves to the fining power of the union. This latter theory could also be phrased as a "waiver" by the employee of his section 7 rights.

The second phrase of the section from which the purpose and objectives of the statute can be discerned is the proviso. While the proviso makes clear that section $8(\mathrm{~b})(1)$ (A) was not intended to interfere with union discipline through suspension or expulsion from membership, the question remains whether union fines also receive the proviso's protection. It seems that some union fines definitely do. Assume that a union has a bylaw that any member who fails to participate in a strike is subject to a fifty dollar fine. The bylaw further states that if the member fails to pay the fine within thirty days, he will be expelled from the union but that no other action will be taken against him. A member violates this bylaw and is fined. He pays

12 See text accompanying note 19 infra.

13 This two-step analysis-examination of the text of the statute followed by a consideration of the objectives or purpose of the statute-is adopted and implemented in Mishrin \& Morris, ON LAW IN CourTs ch. 4 (1965).

14 See, e.g., the definition of the word in Merrian-Webster, ThIro NEw INTERNATIONAL DiCTIONARY 438 (1961): "to compel to an act or choice by force, threat or other pressure ...." 
the fine and files an 8(b)(1)(A) charge with the Board, alleging that he was coerced in the exercise of section 7 activities. Positing that a fine does have the necessary attributes of coercion and that the union member has not waived his section 7 rights, has the union violated section $8(\mathrm{~b})(1)(\mathrm{A})$, or is such conduct sheltered by the proviso? It would seem that the proviso applies to this situation. 'The member was not coerced by the imposition of the fine because he did not have to pay it. He was coerced by the alternative to payment-expulsion-a consequence which is expressly covered by the proviso..$^{15}$

The above hypothetical demonstrates that the real issue is not whether the imposition of fines is coercive, since the imposition exerts no more than social pressure; ${ }^{16}$ rather, the question is whether the means of enforcement of the fine is coercive within the meaning of the statute. ${ }^{17}$ The hypothetical illustrated one means of enforcement -expulsion-which was excluded from the coverage of section 8 (b) (1) (A) even if coercive. Suspension from membership should receive the same treatment. A third method-inducement of the employer to discriminate against the member for failure to pay-is an unfair labor practice under section $8(\mathrm{~b})(2)$ even if it is not coercive under section 8 (b) (1) (A)..$^{18}$ A final nonviolent means of enforcement is the use of legal compulsion to force payment. In a sense, this brings us back to the question whether fines themselves are coercive, on the theory that the coercive aspect (if any) inheres in the payment of the fine rather than in the enforcement itself.

15 It should be noted, however, that even if the union is operating under a union shop clause (requiring continued membership as a condition of employment), § 8 (b) (2), in conjunction with $\$ 8(\mathrm{a})(3)$, prohibits the union from forcing the employer to discharge an employee whom it expels for failure to pay a fine; a union shop clause may be used only to compel payment of "periodic dues and the initiation fees uniformly required." Section 8(a) (3), 61 Stat. 140 (1947), as amended, 29 U.S.C. $\S 158$ (a) (3) (1964); $\$ 8($ b) (2), 61 Stat. 141 (1947), 29 U.S.C. $\$ 158$ (b) (2) (1964); Radio Officers' Union v. NLRB, 347 U.S. 17, 41 (1954), quoted in text accompanying note 57 infra; see note 18 infra.

$16 \mathrm{I}_{\mathrm{t}}$ is here assumed that if no pressure is brought to bear upon a member to pay an imposed fine other than ostracism by his fellow members, the member is not coerced. That social pressure does not constitute coercion within the meaning of the section is borne out by the legislative history. See text accompanying note 35 infra.

17 Professors Cox and Bok, in their casebook on labor law, raise the issue of means of enforcement. They pose this question for discussion:

A union could conceivably attempt to discipline its members by either expelling them from the union, demanding that they pay a prescribed fine or suffer expulsion, or seeking to collect a fine imposed by union rules through legal proceedings. In determining the union's right to discipline its members under Section 8(b) (1), should anything turn on which of these methods the union has employed?

Cox \& Bor, Cases on Labor Law 1012 (6th ed. 1965). As will be seen in the discussion of current litigation in section VIII of this Comment, this has not always been treated as the crucial issue.

18 Section 8(a) (3) prohibits an employer from discriminating against employees so as to encourage or discourage union membership; $\$ 8(\mathrm{~b})(2)$ prohibits a union from causing an employer so to discriminate. Section 8(a) (3), 61 Stat. 140 (1947), as amended, 29 U.S.C. \$158(a) (3) (1964); \$ 8(b) (2), 61 Stat. 141 (1947), 29 U.S.C. $\$ 158(\mathrm{~b})(2)(1964)$. 
Since the legitimacy of all nonviolent means of enforcement except one (legal compulsion) has already been determined, the issue narrows to whether court-enforceable fines are coercive within the meaning of section 8 (b) (1) (A). ${ }^{19}$ However, some clarification is necessary. The issue is not really whether the fine is capable of being enforced through court procedures but rather whether the fined employee is induced ${ }^{20}$ to refrain from exercising his section 7 rights by a justifiable belief that the courts may force him to pay. Thus, in any case where the means which the union might use to collect the fine is not clear, it is necessary to inquire whether the fined member believed that court enforcement would be implemented by the union and, if so, whether it is justifiable to hold the union responsible for such a belief. Deciding this latter question-whether it is justifiable to hold the union responsible for a member's reasonable belief that he will be legally compelled to pay the fine-is difficult if there is no evidence that the union induced in the member such a belief. ${ }^{21}$ The better view seems to be to hold that the union must demonstrate that it has made clear to its members the manner in which its fines would be enforced rather than to hold that a fined member must demonstrate that the union intended that he believe court enforcement would be used. When a union fines a member for refraining from concerted activities, it certainly intends to discourage such abstention; and, since coercion or restraint are prohibited under section $8(\mathrm{~b})(1)(\mathrm{A})$, it does not seem too great a burden to require

19 Concededly, finding court-enforceable fines to be within the proscription of the section produces a rather incongruous result when compared with the conclusion that fines enforced only through expulsion are permissible. This is especially so when the economic loss resulting from termination of membership (such as loss of a union pension) is greater than the amount of the fine. However, there are several grounds upon which this incongruity can be at least partially explained. First of all, complete freedom in this sphere was specifically granted to the union in the statute and must have been intended to give unions a high degree of control over its members. The fact that, in some cases, this freedom may be greater than that obtainable through an illegal means of discipline is purely coincidental and not necessarily undesirable. Secondly, as will be pointed out later in this Comment, see text accompanying notes 54-60 infra, a union "member" in a union shop has not made a free choice in joining the union (which action exposes him to fines), whereas the union shop requirements do not extend to participating in benefit programs (such as pension plans). Therefore, in the latter case, the member has always entered into such a plan voluntarily, realizing that his rights may be terminated at any time through loss of membership. Where the member has also joined the union completely voluntarily, the argument is equally strong that he should be held to have submitted himself to its fining power, and perhaps an exception to any general rule to the contrary is warranted. See section VII infra.

20 It seems that the employee should not have to show that he was motivated to pay the fine by the alternative of court enforcement, but that it is enough that he reasonably believed this alternative to have existed. 'In other words, if the union induces a member to pay his fine by means of a threat both to expel him and to enforce the fine through the courts, the burden should not be on the member to demonstrate that he was motivated by the latter threat.

$\mathbf{2 1}$ However, this problem will rarely arise. In most cases where an unfair labor practice charge is filed against a union for fining its members, the fines will not have been paid, and the union will have already proceeded to enforce them. Even where a member does pay the fine and then files a charge there will usually be some evidence as to the methods of enforcement the union threatened to use. 
the union to make clear that it is acting within the exception of the proviso, i.e., only using the weapons of suspension or expulsion.

An examination of the words of the proviso has thus led to the conclusion that only those fines whose enforcement a union member reasonably believes may be compelled through legal process lie within the proscription of the section and without the proviso. However, it will be seen that another interpretation of the proviso has gathered all union fines within its shelter, reasoning that the words should be read broadly so as to envelop all internal union affairs, including all fines and other forms of discipline. ${ }^{22}$

The above analysis demonstrates that any examination based solely on the text of section 8(b)(1)(A) must necessarily be inconclusive. Although the proscription of union fines is consistent with the words of the section (including the proviso), there are three interpretations of the language of the section under which fines would not be prohibited: fines may not have the necessary physical quality to be coercive; union members may waive their section 7 rights upon joining the union; or the proviso may cover all internal union affairs. It is therefore necessary to resort to an examination of the section's legislative history in order to determine whether to accept any of the above interpretations.

\section{The Legislative History}

Section 8(b) (1) (A) was not included in the Senate bill as it emerged from the Committee on Labor and Public Welfare; ${ }^{23}$ however, in a supplemental statement to the Senate report, several Senators announced their intention to introduce a number of amendments which had been defeated in committee, usually by a vote of seven to six. ${ }^{24}$ Since the section was proposed in this manner, and since the conference committee adopted the Senate's version without change, discussion of the legislative history of section $8(\mathrm{~b})(1)$ (A) must be limited to the statements made in the Senate debates.

Senator Ball introduced section 8(b)(1)(A) with the following statement:

Mr. President, the purpose of this amendment is very simple. It is to insert an unfair-labor practice for unions identical with the first unfair labor practice prohibited to employers in the present act...

The purpose of the amendment is simply to provide that where unions, in their organizational campaigns, indulge in

22 See discussion of cases in section VIII infra.

23 S. Rep. No. 105, 80th Cong., 1st Sess. 35 (1947), in 1 NLRB, Legislattve History of the Labor MANAGEMENT Retations ACr, 1947, at 441 (1948) [hereinafter cited as 1947 LEG. Hist.].

24 S. REP. No. 105, 80th Cong., 1st Sess. 50 (1947), in 11947 LEG. Hist. 456. 
practices which, if an employer indulged in them, would be unfair labor practices, such as making threats or false promises or false statements, the unions also shall be guilty of unfair labor practices. ${ }^{25}$

This introductory statement reveals several of the themes that run throughout the Senate debate. These themes, in turn, reveal the objectives sought by the supporters of section $8(\mathrm{~b})(1)(\mathrm{A}) .^{26}$

The most obvious purpose behind the introduction of the section was to create a quid pro quo for section 8 (a)(1), which made it an unfair labor practice for an employer "to interfere with, restrain, or coerce employees in the exercise of the rights guaranteed in section 7." ${ }^{27}$ Although the relative positions of the employer and the union to the employees make some disparity between the two sections inevitable, ${ }^{28}$ this theme of equal treatment was repeatedly voiced by the sponsors of the amendment. ${ }^{29}$ It may well be asked how this theme can be reconciled with the fact that the phrase "to interfere with" does not appear in section 8(b) (1) (A) but is present in section 8(a)(1). The words did appear in the amendment as introduced, but Senator Ives persuaded the sponsors to delete them. He argued: "They could easily be construed to mean that any conversation, and persuasion, any urging on the part of any person, in an effort to persuade another to

2593 CoNG. REC. 4016 (1947), in 21947 LEG. Hrsr. 1018.

26 Since there is no Senate report on the section and since the House conference report is not illuminating, H.R. REP. No. 510, 80th Cong., 1st Sess. (1947), in 1 1947 LEG. HIST. 505, these objectives are the best available evidence of legislative intent.

27 National Labor Relations Act (Wagner Act) §8(1), 49 Stat. 452 (1935), 29 U.S.C. \$158(a) (1) (1964).

28 This disparity is accurately explicated in the Board's brief in the Associated Home Builders case:

There is considerable legislative history to support petitioner's assertion that Section $8(b)(1)(A)$ was enacted as a union counterpart to the Section 8(a) (1) violation which applies to employers. But this does not mean that all conduct which would violate Section 8 (a) (1) necessarily violates Section 8(b) (1) (A) when committed by a union. . . The obvious differences in status between a union and an employer have always required some differentiation in the application of these counterpart provisions. For example, it would be difficult to envisage an organizing campaign during which the union did not solicit votes with a promise of better working conditions. Such conduct has never been found violative of the Act, but-acknowledging the different status of the employer-settled law bars an employer from promising employees such improvements if they vote against the union. N.L.R.B. v. Exchange Parts Co., 375 U.S. 405.

Brief for Appellee, pp. 42-43, Associated Home Builders of the Greater East Bay, Inc. v. NLRB, 352 F.2d 745 (9th Cir. 1965) (footnote omitted); see Cox \& Bok, op. cit. sipra note 17 , at $287-88$.

29 E.g., 93 Cong. REc. 4023 (1947), in 21947 LEg. Hist. 1028 (remarks of Senator Taft):

The Board has been defining those words for 12 years, ever since it came into existence. Its application to labor organizations may have a slightly different implication, but it seems to me perfectly clear that from the point of view of the employee the two cases are parallel. 
join a labor organization, would constitute an unfair labor practice." 30 Senator Taft, a firm supporter of the amendment, acquiesced, stating that the deletion would have no appreciable effect. ${ }^{31}$ The House conference report, in one of its few references to section 8 (b)(1)(A), accords with this viewpoint. ${ }^{32}$

The above theme seems to indicate a congressional intent to have the Board exercise a broad policing function over union pressures upon employees, one analogous to that exercised over employers. A second theme articulated by Senator Ball concerned the types of pressure to be prohibited. His mention of "threats or false promises or false statements" is indicative of the broad range of activities which the sponsors intended the section to cover. ${ }^{33}$ Although such language probably reaches beyond the limits to which the section will ever be extended in practice, ${ }^{34}$ it vividly demonstrates that the pressure intended to be prohibited was not limited to the use of physical force. One type of pressure definitely intended to be covered was economic reprisal: "The Board may say, 'You can persuade them; you can put up signs . . . but you cannot, by threat of force or threat of economic

3093 Cong. Rec. 4270 (1947), in 21947 Leg. Hrst. 1138.

31 Mr. President, I have consulted with the attorneys and they tell me that elimination of the words "interfere with" would not, so far as they know, have any effect on the court decisions. Eliminating those words would not make any substantial change in the meaning.

93 Cong. REc. 4271 (1947), in 21947 LEg. Hist. 1138.

32 The report stated:

In applying section $8(1)$ of the existing law, the Board has not held to be unfair labor practices acts which constituted "interference" that did not also constitute restraint or coercion. Section $8(1)$ of the present law is written in broad terms, and only by long continued administrative practice has its scope been adequately and properly defined. Concern has heretofore been expressed as to whether such practice would carry over into a corresponding provision of the new section 8 (b) (1), and presumably because of this concern the words "interference with" were omitted from the proposed new section.

H.R. ReP. No. 510, 80th Cong., 1st Sess. 43 (1947), in 11947 LEg. Hrst. 547.

33 In their labor law casebook, Professors Cox and Bok discuss this broad inclusory language used in the debates; after referring to the above remarks of Senator Ball, they continue:

In one of the cases he [Senator Ball] cited by way of example the union had falsely boasted that it had secured a wage increase at another plant and had been recognized by the government as spokesman for all textile workers. In another, the Corn Products case, the "coercion and restraint" was the argument made by an affiliated union that employees should support it instead of an independent union because the lack of equal recognition by government agencies . . . made independent unions "weak and incompetent." In like manner Senator Taft suggested that for a union to issue "defamatory articles and statements" would be made an unfair labor practice. If these explanations were to be accepted at face value, the Board would soon become involved in censoring the exaggerated claims, emotional appeals and aggressive propaganda which are all part of our mores, especially in organizational campaigns. But even the Senators who gave the explanations refused to accept them without a discount. Senator Ball, for example, who had accurately summarized the Corn Products case in giving an example of coercion, agreed a few days later that the facts he had stated involved neither coercion nor restraint.

Cox \& Bor, op. cit. supra note 17, at 289. (Footnotes omitted.)

34 See note 33 sispra. 
reprisal, prevent them from exercising their right to work." "35 It hardly seems debatable that fines, especially when payment is legally compelled, constitute "economic reprisal." In any event, in light of the wide scope of pressures adverted to in the Senate debates, there seems to be no rational basis for believing that fines do not have the necessary attributes to be coercive.

A third theme reflected in Senator Ball's remarks which runs throughout the debates is that this amendment was primarily directed against union organizational tactics. There is no doubt that this was the primary concern of the sponsors of the amendment. ${ }^{36}$ However, it is equally clear that the sponsors were not exclusively concerned with the organizational phase. For example, Senator Taft remarked:

If there is anything clear in the development of labor union history in the past 10 years it is that more and more labor union employees have come to be subject to the orders of labor union leaders. The bill provides for the right of protest against arbitrary powers which have been exercised by some of the labor union leaders.

Mr. President, I think it is fair to say that in the case of many of the unions, the employee has a good deal more of an opportunity to select his employer than he has to select his labor-union leader; and even if he has that opportunity and even if there is a fair election in a union, the man who is elected may have been voted against by various of the employees who did not desire to have that particular man elected as the union leader. In such cases the very fact that they did vote against that man is often used later by the union as a means of coercing such employees ..... ${ }^{37}$

That the amendment would cover union members as well as nonmember employees during the organizational phase was also apparent to Senator Pepper, a member of the opposition: "This amendment is an effort to protect the workers against their own leader, chosen by them under their own constitution and bylaws." 38 Senator Pepper tried to draw an analogy to a corporation, where minority stockholders are not protected against intimidation by the directors. In reply to these insistent remarks, Senator Taft continually played down coercion of union members and emphasized protection of all emTaft).

3593 Cong. REc. 4436 (1947), in 21947 Leg. Hist. 1206 (remarks of Senator

36 See, e.g., 93 Cong. REc. 4433, 4434 (1947), in 21947 LEg. Hirst. 1200, 1203 (remarks of Senator Ball).

3793 Cong. REC. 4023 (1947), in 21947 Leg. Hist. 1028.

3893 Cong. Rec. 4023 (1947), in 21947 LEg. Hrst. 1029. 
ployees. However, he always maintained the position that union members were covered by section 8 (b) (1)(A). ${ }^{39}$ Thus, although the protection of union members might have been a secondary purpose of the section, the fact remains that it was a purpose. This coverage of union members under the section is completely inconsistent with any argument to the effect that union members waive their section 7 rights upon becoming members.

A final theme running through the Senate debates concerns the breadth of the proviso, i.e., whether the proviso was intended to include only rules relating directly to the acquisition or retention of membership, or whether it was to encompass other rules regulating the administration of union affairs. More specifically, the issue is whether it was intended to protect such union disciplinary measures as fines. The proviso was not part of section $8(\mathrm{~b})(1)$ (A) as originally offered by Senator Ball, but was introduced by Senator Holland after he had discussed with Senators Taft and Ball "how seriously, if at all, . . . [section 8(b) (1) (A)] would affect the internal administration of a labor union." 40 Senator Holland continued:

Apparently it is not intended by the sponsors of the amendment to affect at least that part of the internal administration which has to do with the admission or the expulsion of members, that is with the question of membership.

In other words . . . the inserted words would make it clear that the pending amendment would have no application to or effect upon the right of a labor organization to prescribe its own rules of membership either with respect to beginning or terminating membership. ${ }^{41}$

These remarks by the author of the proviso seem to indicate that it should be limited to its literal language, i.e., to ensuring that the union would be completely free to choose or expel its members. That Congress intended to effectuate this limitation is equally clear in the union shop provisions, sections $8(\mathrm{a})(3)$ and $8(\mathrm{~b})(2)$, and in the debates on these provisions. ${ }^{42}$ It certainly is not apparent from the

39 The replies of Senator Taft to Senator Pepper included the following:

Mr. President, let me point out that the amendment protects men who may not be members of unions at all. In fact, many of these cases of coercion are cases in which there never has been a certification of a union ....

...

Coercion is not merely against union members; it may be against all employees.

93 Cong. ReC. 4023, 4024 (1947), in 2 1947 LEG.. Hist. 1029, 1030.

4093 Cong. Rec. 4271 (1947), in 21947 LEG. Hist. 1139.

4193 Cong. Rec. 4271, 4272 (1947), in 21947 LEG. Hist. 1139, 1141.

42 As explained in note 15 supra, these sections prohibit a union operating under a union shop clause from causing the discharge of a member expelled for any reason 
remarks of Senator Holland that Congress intended to refrain from interfering with all union disciplinary policies. Furthermore, such an interpretation would seem contrary to the clear intent of Congress to protect union members under section $8(\mathrm{~b})(1)(\mathrm{A}) .{ }^{43}$ Were a union completely unfettered in disciplining its members, one might ask how any protection would be given to union members under the section.

Further support for a narrow interpretation of the proviso and for protecting union members under the section can be found in Senator Wiley's general remarks upon the Senate bill:

Third. None of these provisions interferes unduly with union affairs, except to the extent necessary to protect the individual rights of employees. I stress individual rightsthe individual rights of the employee who also is an American citizen, and who, even if he gets mixed up with racketeers, is entitled to our consideration and our defense. ${ }^{44}$

However, doubt is cast upon this interpretation from a most unusual source-Senator Ball, who had originally introduced section $8(b)(1)(A)$. In accepting Senator Holland's proviso, he stated: "[T] he amendment . . . is perfectly agreeable to me. It was never the intention of the sponsors of the pending amendment to interfere with the internal affairs or organization of unions." 45 Later he stated, concerning the proviso:

That modification is designed to make it clear that we are not trying to interfere with the internal affairs of a union which is already organized. All we are trying to cover is the coercive and restraining acts of the union in its effort to organize unorganized employees. However, the proviso would not go so far as to permit the union to adopt rules au-

other than nonpayment of dues, but they do not interfere with the union's right to expel the member. Senator Taft made this clear in the Senate debates:

The pending measure [the union shop provisions] does not propose any limitation with respect to the internal affairs of unions. They still will be able to fire any members they wish to fire, and they will be able to try any of their members. All that they will not be able to do, after the enactment of this bill, is this: If they fire a member for some reason other than nonpayment of dues they cannot make his employer discharge him from his job and throw him out of work. That is the only result of the provision under discussion.

93 Cong. Rec. 4193 (1947), in 21947 LEg. Hist. 1097.

43 This intent is evident in the legislative history previously referred to in the text. The intent of Congress to protect union members from union discipline is specifically written into the second union unfair labor practice. Section $8(\mathrm{~b})(2)$ protects all employees:

(b) It shall be an unfair labor practice for a labor organization or its agents .... (2) to cause or attempt to cause an employer to discriminate against an employee in violation of subsection (a) (3) of this section ....

61 Stat. 141 (1947), 29 U.S.C. § 158(b) (2) (1964).

4493 Cong. Rec. 5001 (1947), in 2 1947 LEG. Hist. 1472.

4593 CoNG. REC. 4272 (1947), in 21947 LEg. HIst. 1141. 
thorizing its agents to threaten and coerce nonunion members in an effort to persuade them to join. The modification covers the requirements and standards of membership in the union itself. ${ }^{46}$

Thus Senator Ball seems to have envisioned a broader scope for the proviso than that described by Senator Holland, who introduced this amendment. He does not say that union members are not protected under the section, but he does focus his concern on the nonunion employee during the organizational phase. Perhaps this can be explained in part by the fact that this does seem to have been the main purpose of the section. However, to the extent that an inference of noncoverage of union members can be drawn from Senator Ball's remarks, they seem irreconcilable with many statements of Senator Taft. ${ }^{47}$

Before the legislative history of section $8(\mathrm{~b})(1)$ (A) was consulted, three interpretations of the section under which union fines would not be covered were enumerated. The legislative history, with the possible exception of the above remarks of Senator Ball, has proved to be incompatible with all these theories. First, fines definitely possess the necessary attributes to be coercive within the meaning of the section. Secondly, since union members are protected by the section, it does not seem possible to hold that they waive their section 7 rights upon joining the union. The only confusion in the legislative history is over the breadth of the proviso. Senator Ball's remarks do indicate that the proviso covers internal union affairs. From this it could be inferred that all union discipline is protected. However, such reasoning is incompatible with the above-stated conclusion that union members are protected by the section. As was pointed out before, were the proviso to cover all union discipline, union members would receive no protection whatsoever under the section. Since the legislative history clearly demonstrates that union members are protected and since Senator Ball never denied this, his broad reference to internal union affairs should be read in light of the purpose to which his remarks were directed-an assurance that he, as sponsor of the section, had no objection to having the proviso added. Viewed in

4693 Cong. Rec. 4433 (1947), in 2 1947 Leg. Hist. 1200.

47 This seeming inconsistency might have contributed to the doubts at least one Senator had as to the effectiveness of the proviso:

It appears to me that by prohibiting unions from interfering with the employees' exercise of their rights relating to the selection of representatives, and in the next sentence stating that such a prohibition shall not impair the right of a union to prescribe its own rules with respect to the acquisition or retention of membership, we are outlining the boundaries of a legalistic battlefield which may lead to unlimited argument.

93 CoNG. Rec. 5005 (1947), in 21947 LEG. HIST. 1479 (remarks of Senator Hatch). 
this context, his use of the words "internal union affairs" can be explained as a misstatement and as referring only to union rules with respect to acquisition or retention of members. ${ }^{48}$ Certainly this explanation is most consistent not only with the words of the statute but also with the intent expressed by the author of the proviso, Senator Holland.

A tentative answer to the query posed at the beginning of this Comment is now possible. The words of the section as well as its purpose as revealed by the legislative history lead to the conclusion that union fines which the member reasonably believes might be enforced through legal proceedings fall within the prohibition of section 8 (b) (1) (A). However, the factors which limit the conclusiveness of this answer must be kept in mind. Nowhere in the legislative history is there a statement that such fines are prohibited by the section. The most that can be said is that these fines seem to fall within the reason for the rule and therefore within the "intention of the statute." 49

A further problem is the limited reliability of the legislative history relating to this section. Since the section was added to the bill as proposed by the Senate committee and received scant attention in the conference report, reliance must be exclusively on the Senate debates, a notably inferior source of legislative history. ${ }^{50}$ Nevertheless, in the present case the only committee work was that of the conference committee. Since the report of this committee is unrevealing, it is necessary to use the best material available. While this material isat most-evidence of the intent of only one-half of Congress, it is indicative of the viewpoints of those who introduced and actively debated the section. To the extent that Congress had any "intent" at all regarding this section, the Senate debates best reveal that intent.

48 Of course, it is conceivable that the proviso could cover more than rules directly relating to acquisition or retention of membership and yet less than all internal union affairs. However, there seems to be no rational basis for drawing a line at any particular point between these two extremes.

49 For an analysis of the reasoning behind the use of this language, see Fuller, The Morality of Law 83-87 (1964).

50 The inferiority of this source is pointed out in the following passage:

Yet, while members of Congress formally vote for or against these words, it is highly unrealistic to assume that each legislator has a detailed understanding of what those words specifically encompass ....

Most votes are cast in terms of what is understood to be the central general purpose of the proposed legislation. . . . [M] ost votes on pending legisiation are determined by no more knowledge than of this central core of the general purpose of the proposed statute.

The detailed work of Congress is carried on in committees, and rarely is much close attention paid to the sense in which the language of bills is used outside of committee consideration. Moreover, Congress usually relies on the committee's work . . . The "intent of Congress" as to the details of enacted legislation will generally be found-if it can be found at all-somewhere in committee work.

Mishkin \& Morris, ON LAW IN Courts 404-05 (1965). 


\section{The Labor Management Relations Act}

The tentative conclusion derived from the words of the statute and the legislative history should now be tested against the background of the act of which section 8 (b) (1) (A) is but one integral part. The purpose of the National Labor Relations Act, as originally adopted in 1935, was to foster collective bargaining and, collaterally, to furnish employees with sufficient protection from employers so that they could independently participate in such bargaining. As stated by one commentator, "the Wagner Act established the twin rights to organize and bargain collectively and made it government policy to encourage unionization and collective bargaining." 51 Unions flourished under this governmental encouragement, and, by 1947, many observers felt that they had become too powerful. The result was the Labor Management Relations Act (Taft-Hartley Act) :

[T] he Taft-Hartley Act was the product of diverse forcesthe off-spring, a critic might say, of an unhappy union between the opponents of all collective bargaining and the critics of the unions' abuses of power. The former group was probably the more influential of the two in writing the TaftHartley amendments, for organized labor's unfortunate decision to oppose all legislation left its sympathetic critics in a dilemma. $^{52}$

The purpose and policy of the act, as stated in its first section, was

to prescribe the legitimate rights of both employees and employers . . . to provide orderly and peaceful procedures for preventing the interference by either with the legitimate rights of the other, to protect the rights of individual employees in their relations with labor organizations... . to define and proscribe practices on the part of labor and management which . . . are inimical to the general welfare, and to protect the rights of the public in connection with labor disputes ... .53

The act retained protection of employees from employer unfair labor practices; but, recognizing that powerful unions sometimes interfered with the legitimate rights of employees, proscribed certain union conduct as well. As aptly described by one commentator, "the government, instead of aiding one side, now stands in the center." 54

51 Cox \& Bor, op. cit. supra note 17, at 129.

52 Id. at 133.

53 Labor Management Relations Act (Taft-Hartley Act) §1(b), 61 Stat. 136 (1947), 29 U.S.C. \&141(b) (1964). (Emphasis added.)

$54 \mathrm{Cox} \& \mathrm{Bor}$, op. cit. supra note 17, at 134-35. 
Finding that court-enforceable union fines violate section $8(\mathrm{~b})$ (1) (A) seems compatible with the purposes of the Labor Management Relations Act. Protection of only nonunion employees is certainly not an enumerated or readily apparent policy. In fact, the existence of such a policy becomes very unlikely if one accepts the above-mentioned proposition that the opponents of organized labor were the most influential group in the enactment of this legislation. If these individuals were responsible for passage of the act, their intent is certainly relevant, and they undoubtedly intended to protect union members along with other employees.

Perhaps the strongest argument for prohibiting these fines under section $8(b)(1)$ (A) is that a contrary result would open an enormous loophole in two other sections of the Labor Management Relations Act, 8(a) (3) and 8(b) (2)..$^{55}$ Section 8(a) (3) makes lawful the inclusion in a collective bargaining agreement of a union security clause, requiring as a condition of continued employment that all employees become members of the union within thirty days after commencing work for the employer. However, a proviso to the section limits this membership requirement to tendering "the periodic dues and the initiation fees uniformly required as a condition of acquiring or retaining membership." ${ }^{56}$ It is well settled that the union security clause can be used for no other purpose than requiring that employees help bear the financial burdens of their statutory bargaining representative. In the words of the Supreme Court:

This legislative history clearly indicates that Congress intended to prevent utilization of union security agreements for any purpose other than to compel payment of union dues and fees. Thus Congress recognized the validity of unions' concern about "free riders," i.e., employees who receive the benefits of union representation but are unwilling to contribute their share of financial support to such union, and gave unions the power to contract to meet that problem while withholding from unions the power to cause the discharge of employees for any other reason. ${ }^{57}$

If unions are permitted to require membership in the union under a union security clause and then to use this membership as a basis for imposing court-enforceable fines upon those who are unwilling to participate in union activities, the union security agreement is clearly being used for a "purpose other than to compel payment of union dues and fees." 58 This is not to say that unions operating

55 Section 8(a) (3), 61 Stat. 140 (1947), as amended, 29 U.S.C. $\$ 158$ (a) (3) (1964); \& 8(b) (2), 61 Stat. 141 (1947), 29 U..S.C. \$ 158(b) (2) (1964). (1964).

56 Section 8(a)(3), 61 Stat. 140 (1947), as amended, 29 U.S.C. \$158(a) (3)

57 Radio Officers' Union v. NLRB, 347 U.S. 17, 41 (1954).

58 Ibid. 
under security agreements should not be permitted to fine their members, but only that these fines should be enforceable only through threats of suspension or expulsion from membership. The member fined under these latter circumstances is not compelled to pay the fine but only to choose between obeying union rules and losing union membership; and, if he chooses the latter, it will not result in the loss of his job. The evil inherent in fines enforceable through legal compulsion is that the union security clause is used not only to obtain dues payments but also to fasten upon the employee a legal obligation to pay fines incurred for refusal to participate in union activities.

It is arguable that an employee who is a union "member" only to the extent required by a union security clause, i.e., one who merely is on the union rolls ${ }^{5 \theta}$ and pays dues, is not subjected to the compulsion described above because this "membership" is not a sufficient legal relationship to compel payment of union fines. This argument rests, however, upon two unwarranted assumptions. First, most members of a union shop will not be able to prove that upon joining the union they did not intend to bind themselves beyond the minimal legal requirements. A new employee is told that he must join the union within thirty days; only the most belligerent and vociferous employee will make a formal protest sufficient so to limit his membership and to serve as evidence of such limitation. Although the great majority of employees will simply comply-signing the necessary

59 Some commentators have argued that, under the Union Starch doctrine, Union Starch \& Ref. Co. v. NLRB, 186 F.2d 1008 (7th Cir.), cert. denied, 342 U.S. 815 (1951), employees in a union shop are not compelled to join the union at all but merely to pay dues. Summers, Freedom of Association and Compulsory Unionism in Sweden and the United States, 112 U. PA. L. Rev. 647, 686 (1964); Toner, The Taft-Hartley Union Shop Does Not Force Anyone To Join Union, 6 LAB. L.J. 690 (1955). However, no case, including Union Starch, has gone so far. In Union Starch, the Seventh Circuit's statement of the case, as well as the facts, make it clear that the employee must offer to "join" the union to the extent of being willing to pay dues. The court stated:

The principal question involved is whether employees who request union membership and tender initiation fees and dues, but fail to comply with other union-imposed conditions for acquisition of membership, are protected by the Act from discharge under the terms of a valid union security agreement.

186 F.2d at 1010. (Emphasis added.) The employees were discharged because "they had failed to file an application card, attend a meeting of and take an oath of loyalty to the Union," $i d$. at 1011, and the court held this to be an unfair labor practice. However, although the employees in this case were not willing to do much else, they were willing to "join" the union. Any doubt that this was required of employees in a union shop was laid to rest in a recent Supreme Court decision relating to the validity of an "agency shop" in a right-to-work state:

Of course, if the union chooses to extend membership even though the employee will meet only the minimum financial burden, and refuses to support or "join" the union in any other affirmative way, the employee may have to become a "member" under a union shop contract, in the sense that the union may be able to place him on its rolls. The agency shop arrangement proposed here removes that choice from the union and places the option of membership in the employee while still requiring the same monetary support as does the union shop.

NLRB v. General Motors Corp., 373 U.S. 734, 743-44 (1963). (Footnote omitted.) It is thus apparent that it is only the agency shop and not the union shop which does not compel membership. 
papers and paying the initiation fees-this in no way indicates that they have voluntarily joined the union or that they would have joined in the absence of the union security clause. Secondly, the argument also makes the unwarranted assumption that if a member can prove that he so limited his union membership, each and every state court before whom an action for payment is brought will reach the same conclusion-that such limited membership is not a relationship sufficient legally to bind the employee. To the extent that an employee under a union shop contract is held to have "joined" the union -whether by reason of insufficient protest at the time of joining, lack of proof of such protest or the particular state law involvedand is therefore held liable to pay a fine, the union shop contract is being used for a "purpose other than to compel payment of union dues and fees." ${ }^{60}$ To hold that section 8(b)(1) (A) permits the imposition of court-enforceable fines where the member has joined because of a union security clause, therefore, would clearly be inconsistent with the union shop provisions, sections $8(\mathrm{a})(3)$ and $8(\mathrm{~b})(2)$.

\section{The Labor-Management Reporting and DisClosure ACT OF 1959}

The conclusion that section 8 (b) (1) (A) prohibits court-enforceable union fines blends very well with the purposes and policies of the whole act. It is necessary, however, to make a limited inquiry into one further piece of labor legislation, the Labor-Management Reporting and Disclosure Act of 1959 (Landrum-Griffin Act). ${ }^{61}$ As the Supreme Court has so aptly stated:

To be sure, what Congress did in 1959 does not establish what it meant in 1947. However, as another major step in an evolving pattern of regulation of union conduct, the 1959 Act is a relevant consideration. Courts may properly take into account the later Act when asked to extend the reach of the earlier Act's vague language to the limits which, read literally, the words might permit. We avoid the incongruous result implicit in the Board's construction by reading $\S 8$ (b) (1) (A), which is only one of many interwoven sections in a complex Act, mindful of the manifest purpose of the Congress to fashion a coherent national labor policy. ${ }^{62}$

Thus it must be ascertained whether prohibiting court-enforceable fines under section $8(\mathrm{~b})(1)(\mathrm{A})$ is consistent with the terms and purposes of the 1959 legislation.

60 Radio Officers' Union v. NLRB, 347 U.S. 17, 41 (1954).

6173 Stat. 519 (1959), 29 U.S.C. \$\$ 401-531 (1964).

62 NLRB v. Local 639, Teamsters Union, 362 U.S. 274, 291-92 (1960). 
The Landrum-Griffin Act was the first congressional attempt to regulate directly the internal affairs of unions. ${ }^{63}$ This regulation included the following:

Certain provisions required that elections be held periodically for local and national union officers and that union members be assured a right to vote, to nominate candidates, to run for office, to comment upon candidates for union office, etc. Every union member was given an equal right to attend membership meetings and to participate in the voting and deliberations at such meetings. ${ }^{64}$

The act contains a provision relating directly to union discipline, section 101(a) (5), which states that a member may not be "fined, suspended, expelled, or otherwise disciplined" until he receives a specified degree of procedural due process. ${ }^{65}$ This provision points out two superficial inconsistencies between the above interpretation of section 8(b)(1)(A) and the 1959 legislation. First, section 101 (a) (5) seems to treat "fines" as a legitimate form of union discipline. To a certain extent this is true; for the language of the section to be meaningful, some fines must be legitimate. However, the proposed interpretation of section $8(\mathrm{~b})(1)(\mathrm{A})$ also accepts some fines as legitimate, proscribing only those fines imposed upon section 7 activities and enforceable through legal compulsion.

The other seeming inconsistency raises a more serious problem. Congress did not specifically deal with internal union affairs in 1947; when it did direct itself to internal union affairs and union discipline

63 In its Declaration of Findings, Purposes and Policy, the act states:

The Congress further finds, from recent investigations in the labor and management fields, that there have been a number of instances of breach of trust, corruption, disregard of the rights of individual employees, and other failures to observe high standards of responsibility and ethical conduct which require further and supplementary legislation that will afford necessary protection of the rights and interests of employees and the public generally as they relate to the activities of labor organizations, employers, labor relations consultants, and their officers and representatives.

Labor-Management Reporting and Disclosure Act of 1959 (Landrum-Griffin Act) \$2(b), 73 Stat. 519 (1959), 29 U.S.C. \$ 401 (b) (1964).

$64 \mathrm{Cox} \& \mathrm{BoK}$ op. cit. supra note 17, at 136-37.

65 No member of any labor organization may be fined, suspended, expelled, or otherwise disciplined except for nonpayment of dues by such organization or by any officer thereof unless such member has been (A) served with written specific charges; (B) given a reasonable time to prepare his defense;

(C) afforded a full and fair hearing.

73 Stat. 523 (1959), 29 U.S.C. $\$ 411$ (a) (5) (1964). Another section of the act prohibits the use of the disciplinary powers enumerated above to prevent any member from exercising any right conferred upon him by the act. Section 609, 73 Stat. 541 (1959), 29 U.S.C. $\$ 529$ (1964). This provision is analogous to $\$ 8$ (a) (4) of the National Labor Relations Act, 49 Stat. 453 (1935), as amended, 29 U.S.C. \& 158(a) (4) (1964), which makes it an unfair labor practice for an employer to discriminate against an employee for filing charges or giving testimony under that act. Section 8(b) (1) (A) has been held to place a corresponding proscription upon a union. Roberts v. NLRB, 350 F.2d 427 (D.C. Cir. 1965); Local 138, Int'1 Union of Operating Eng'rs, 148 N.L.R.B. 679 (1964). 
in 1959, regulation was limited to the procedural aspects of union discipline. According to the maxim expressio unitis est exclusio alterius, this limitation in the 1959 legislation would seem to indicate a congressional intent to abstain from regulation of the union's substantive right to fine once procedural due process has been furnished. However, this result does not necessarily follow. While it is true that congressional concern in enacting section $8(\mathrm{~b})(1)(\mathrm{A})$ of the 1947 act was primarily with protecting employee rights rather than the rights of union members vis-à-vis the union, this does not indicate that Congress intended to restrict the protection of section 7 rights when to provide such protection would impinge upon internal union affairs. When a union member is protected in the exercise of his section 7 rights, any ensuing regulation of internal union affairs is purely incidental. ${ }^{66}$ Any suggestion that section 101(a)(5) of the 1959 act bars all applications of section 8(b)(1)(A) which would have this incidental effect is dispelled by section 103 of the 1959 act: "Nothing contained in this title shall limit the rights and remedies of any member of a labor organization under any State or Federal law . . . " 67 Thus on closer inspection the proscription of courtenforceable union fines under section $8(\mathrm{~b})(1)(\mathrm{A})$ is not incompatible with the 1959 legislation. The 1947 legislation creates an incidental regulation over the power of unions to levy some fines, while the 1959 act regulates the procedural aspects of all union fines.

\section{The Relevance of Related Court Decisions}

It has been seen that holding court-enforceable fines violative of section 8 (b) (1) (A) is compatible with both the Labor Management Relations Act and the Landrum-Griffin Act. It remains to be seen

66 One may question whether the prohibition of court-enforceable union fines is really a regulation of internal union affairs at all. If a union member is fined for working during a strike or exceeding production ceilings and is legally compelled to pay the fine, it seems that he is being affected in his employment, rather than in his union, relationship. See quotation in text accompanying note 119 infra. On the other hand, if he is expelled or suspended from the union for failure to pay such a fine, it is solely an internal union matter and is exempted from $\S 8(\mathrm{~b})(1)(\mathrm{A})$ by the express words of the proviso.

8773 Stat. 523 (1959), 29 U.S.C. $\$ 413$ (1964). A further demonstration that the 1959 legislation was not intended to change the substantive rights of a union to discipline its members is found in the legislative history. Representatives Iandrum and Griffin, sponsors of the act, both assured Congress that the proviso to $\S 8(\mathrm{~b})(1)$ (A) would not be affected. In the words of Representative Griffin:

The labor reform legislation before the House at this time is directed at the regulation of the internal affairs of unions. It does not touch or deal in any way with the admission to, or retention of, membership in a union. There is a proviso in the Taft-Hartley Act which union leaders and the union members want preserved. I refer to a proviso to Section $8(\mathrm{~b})$. . I . I personally think that in some instances this privilege has been abused by some unions. However, our committee did not go into that matter in its hearings. . . [It] is outside of the scope of the legislation and the hearings that were held on labor reform legislation.

105 Cong. Rec. 15722-23 (1959), in 2 NLRB, Legistative History of the LaboRManagement Reporting ANd Disclosure ACt of 1959, at 1649 (1959). 
whether this interpretation of section $8(\mathrm{~b})(1)(\mathrm{A})$ is in accord with court decisions ${ }^{68}$ on related problems.

\section{A. Waiver of Rights}

The theory that an employee waives his section 7 rights upon becoming a union member has already been discussed. The Supreme Court has stated that a statutory bargaining representative may effectively waive the employee's right to strike in a collective bargaining agreement: "Provided the selection of the bargaining representative remains free, such waivers contribute to the normal flow of commerce and to the maintenance of regular production schedules." ${ }^{69}$ It seems that this result is necessary in order to further the basic purposes of the National Labor Relations Act. The employee was given the right to strike in order to strengthen his ability to bargain collectively; ${ }^{70}$ when this object has been fulfilled, it seems perfectly consistent to remove that right for the duration of the contract. There are no such compelling reasons for taking away all of an employee's section 7 rights when he joins a union. In any event, the Supreme Court has not evidenced any tendency so to broaden the waiver theory.

\section{B. Exclusive Federal ${ }^{71}$ Jurisdiction}

Under the rule of Garner $v$. Teamsters Union, ${ }^{72}$ the Supreme Court has held that state courts cannot regulate union activity which "arguably" violates section 8(b) of the National Labor Relations Act. In International Ass' $n$ of Machinists $v$. Gonzales, ${ }^{73}$ a union member sued in a state court, alleging expulsion contrary to the union constitution and bylaws and seeking damages and reinstatement. His damages resulted from being unable to obtain employment because of loss of membership. The Supreme Court held that action by the state court was proper in this case. Mr. Justice Frankfurter admitted:

6s The discussion in this section will be limited to court decisions since the position of the Board on the specific issue under discussion is now clear. See section VIII infra.

69 Mastro Plastics Corp. v. NLRB, 350 U.S. 270, 280 (1956). (Italics in original.)

70 The policy behind the 1935 legislation, $\S 7$ of which protected the employee in his right to strike, was stated as follows:

It is hereby declared to be the policy of the United States to eliminate the causes of certain substantial obstructions to the free flow of commerce . . . by encouraging the practice and procedure of collective bargaining and by protecting the exercise by workers of full freedom of association, self-organization, and designation of representatives of their own choosing, for the purpose of negotiating the terms and conditions of their employment or other mutual aid or protection.

National Labor Relations Act (Wagner Act) §1, 49 Stat. 449 (1935).

${ }^{71}$ As used herein, "Federal" encompasses the National Labor Relations Board, with appeal to the United States courts of appeals and certiorari to the United States Supreme Court.

72346 U.S. 485 (1953).

73356 U.S. 617 (1958). 
[I]t might be abstractly justifiable, as a matter of wooden logic, to suggest that an action in a state court by a member of a union for restoration of his membership rights is precluded. In such a suit there may be embedded circumstances that could constitute an unfair labor practice under $\S 8(\mathrm{~b})(2)$ of the Act. . . . But the protection of union members in their rights as members from arbitrary conduct by unions and union officers has not been undertaken by federal lawe, and indeed the assertion of any such power has been expressly denied. ${ }^{74}$

He then quoted from the proviso to section $8(\mathrm{~b})(1)(\mathrm{A})$. The italicized language above has been used to argue that section $8(\mathrm{~b})(1)(\mathrm{A})$ does not proscribe union fines. ${ }^{75}$ However, the context in which this language is used makes it perfectly clear that Mr. Justice Frankfurter was referring only to the lack of regulation over the union's right to suspend or expel its members and not to its complete freedom in matters of union discipline. ${ }^{76}$

A more recent Supreme Court decision, Local 100, United Ass'n of Journeymen $v$. Borden, ${ }^{77}$ explained the Gonzales decision as follows:

The Gonzales decision, it is evident, turned on the Court's conclusion that the lawsuit was focused on purely internal union matters, i.e., on relations between the individual plaintiff and the union not having to do directly with matters of employment, and that the principal relief sought was restoration of union membership rights. ${ }^{78}$

In Borden, on facts very similar to Gonzales, ${ }^{79}$ the Court held that the state suit was barred because "the suit involved here was focused principally, if not entirely, on the union's actions with respect to Borden's efforts to obtain employment." 80 But Borden is extremely relevant here for another reason. Borden was a union member, and the Court held that the relevant provision of the National Labor

74 Id. at 619-20. (Emphasis added.)

75 Brief for Appellee, p. 25, Associated Home Builders of the Greater East Bay, Inc. v. NLRB, 352 F.2d 745 (9th Cir. 1965) ; Brief for Appellee, p. 25, Allis-Chalmers Mfg. Co. v. NLRB, No. 14853, 7th Cir. Sept. 13, 1965.

76 For a discussion of the question whether fines affect members in their employment rights rather than in their rights as members, see note 66 stipra.

77373 U.S. 690 (1963).

78 Id. at 697.

79 Borden, a union member, after tentatively getting a job on a construction project, was denied referral by the union (hiring was done through union referral). He sued the union, alleging willful interference with his right to contract and breach of the union's promise not to discriminate in referral among members. Id. at 691-92.

$80 \mathrm{Id}$. at 697 . 
Relations Act was section 8 (b)(1)(A). ${ }^{81}$ Here, then, is a specific affirmance of the position that union members are protected under this section.

\section{Violations of Section $8(b)(1)(A)$}

The Supreme Court, in NLRB v. Local 639, Teamsters Union, ${ }^{\mathbf{2}}$ has held that peaceful picketing by a minority union for the purpose of immediate recognition does not violate section $8(\mathrm{~b})(1)(\mathrm{A}) .^{83}$ The decision hinged on considerations pertaining to the particular conduct involved:

In the sensitive area of peaceful picketing Congress has dealt explicitly with isolated evils which experience has established flow from such picketing. Therefore, unless there is the clearest indication in the legislative history of $\S 8(\mathrm{~b})(1)(\mathrm{A})$ supporting the Board's claim of power under that section, we cannot sustain the Board's order here. ${ }^{84}$

However, some language in the opinion treats the kind of conduct which is coercive under the section rather narrowly: "The note repeatedly sounded [in the legislative history] is as to the necessity for protecting individual workers from union organizational tactics tinged with violence, duress, or reprisal." 85 This language has been used to argue that conduct such as the imposition of fines is excluded from the proscription of the section. ${ }^{86}$ Such an argument ignores later language in the opinion:

[T] he central theme of [the debate] . . . was not the curtailment of the right peacefully to strike . . . but the elimination of the use of repressive tactics bordering on violence or involving particularized threats of economic reprisal. ${ }^{87}$

81 Notwithstanding the state court's contrary view, if it is assumed that the refusal and the resulting inability to obtain employment were in some way based on respondent's actual or believed failure to comply with internal union rules, it is certainly "arguable" that the union's conduct violated $\S 8$ (b) (1) (A), by restraining or coercing Borden in the exercise of his protected right to refrain from observing those rules ...

Id. at 694. (Italics in original.)

82362 U.S. 274 (1960).

83 Since this picketing was conducted within twelve months after a valid election and was for the purpose of recognition, it would now be an unfair labor practice under $\S 8$ (b) (7) (B), which was added in 1959. 73 Stat. 544 (1959), 29 U.S.C. $\$ 158$ (b) (7) (B) (1964).

84362 U.S. at 284.

85 Id. at 286.

86 Brief for Appellee, p. 22, Associated Home Builders of the Greater East Bay, Inc. v. NLRB, 352 F.2d 745 (9th Cir. 1965); Brief for Appellee, p. 21, Allis-Chalmers Mfg. Co. v. NLRB, No. 14853, 7th Cir., Sept. 13, 1965 ; Brief for Appellee, p. 26, Scofield v. NLRB, appeal docketed, No. 14698, 7th Cir., June 28, 1964.

87 NLRB v. Local 639, Teamsters Union, 362 U.S. 274, 287 (1960). 
[Section] 8(b)(1)(A) is a grant of power to the Board limited to authority to proceed against union tactics involving violence, intimidation, and reprisal or threats thereof-conduct involving more than the general pressures upon persons employed by the affected employers implicit in economic strikes. $^{88}$

That physical violence or even scienter are not necessary to have an 8 (b) (1) (A) violation is demonstrated by the more recent Supreme Court decision in International Ladies' Garment Workers' Union v. $N L R B .^{89}$ Here the Court affirmed the finding of an $8(\mathrm{~b})(1)(\mathrm{A})$ violation where the union accepted exclusive bargaining authority at a time when, in fact, it did not have the support of a majority of the employees, although the union had a bona fide belief that it did represent a majority. ${ }^{90}$

\section{Mandatory Bargaining Subjects}

Under sections $8(a)(5)$ and $8(b)(3)$ it is an unfair labor practice for an employer or the statutory bargaining representative of the employees to refuse to bargain collectively. ${ }^{91}$ Section 8 (d) defines this duty as follows: "to meet at reasonable times and confer in good faith with respect to wages, hours, and other terms and conditions of employment . . . ." ${ }^{92}$ With regard to these mandatory bargaining subjects, both the employer and the union must bargain but need not acquiesce, i.e., they may insist to an impasse. ${ }^{.3}$ Both the Seventh and the Ninth Circuits have held union rules levying fines to be mandatory bargaining subjects.

In Associated Home Builders of the Greater East Bay, Inc. v. $N L R B,{ }^{94}$ the Ninth Circuit avoided deciding whether the union violated 8 (b) (1) (A) in fining those of its members who exceeded production ceilings set down in the union rules by holding that it violated section 8 (b) (3) in unilaterally establishing the production ceilings:

88 Id. at 290.

89366 U.S. 731 (1961).

90 This decision supports the conclusion reached earlier in this Comment to the effect that the union should have the burden of demonstrating that it made clear to its members that fines would not be court-enforced. See text accompanying notes $20-21$ sipra. If a union can be held to have violated \$8(b)(1) (A) without any willful action, surely this latter burden is not too severe.

91 Section 8(a) (5), 49 Stat. 453 (1935), 29 U.S.C. $\$ 158$ (a) (5) (1964); § 8(b) (3), 61 Stat. 141 (1947), 29 U.S.C. \$ 158(b) (3) (1964).

92 Section 8(d), 61 Stat. 142 (1947), 29 U.S.C. $\$ 158$ (d) (1964).

93 NLRB v. American Nat'l Ins. Co., 343 U.S. 395 (1952). However, insisting to an impasse upon a non-mandatory subject is a refusal to bargain in violation of the act. NLRB v. Wooster Div. of Borg-Warner Corp., 356 U.S. 342 (1958).

94 352 F.2d 745 (9th Cir. 1965). 
The rules relating to the limitation of production are plainly rules adopted for the purpose of establishing the terms and conditions of employment of union members. The rule is not directed merely to the employees; it has a direct impact upon the employer. It fixes the conditions and terms under which he may procure the services of his employees. ${ }^{95}$

This case does not, however, shed much light on the $8(\mathrm{~b})(1)$ (A) issue. The court held that the proviso to this section was inapplicable, since the union rule "was an attempt to prescribe the terms and conditions of employment and it was not confined to any purely internal concern of the Unions." 96 Nevertheless, its conclusion that this was not a purely internal matter was based on the interest of the employer in such a rule rather than on a concern for the union member in matters relating to his employment relationship. By contrast, in Allen Bradley Co. v. NLRB ${ }^{97}$ the Seventh Circuit case treating union fines as a mandatory bargaining subject, the court squarely and forcefully stated, albeit in dictum, that fines imposed for refusing to strike were an $8(\mathrm{~b})(1)(\mathrm{A})$ violation:

Section 7 protects an employee in his right to refrain from concerted activities and this includes, of course, the right to refuse to participate in or recognize a strike. Coercion or interference with that right, whether by the employer or by the union, is made an unfair labor practice by the terms of the Act. So far as material to the instant situation, the Act permits no impairment of the right of an employee to work, with the corollary right of the employer to utilize his services. ${ }^{98}$

In this case the union was not operating under a union shop contract. Fourteen employees had each been fined 100 dollars by the union for working during a strike, and local court actions had been commenced to collect the fines. The company thereafter insisted to an impasse on a contract clause limiting the union's right to discipline or fine its members. The Board found that the employer had refused to bargain under section $8(a)(5)$; the Seventh Circuit reversed, finding no protection for the union in the proviso to section $8(\mathrm{~b})(1)(\mathrm{A})$ :

[T] here is nothing in the situation before us which indicates that such fines bore any relation to the "acquisition or re-

$95 \mathrm{Id}$. at 750.

96 Ibid. One apparent reason for dealing with the proviso to $\$ 8(\mathrm{~b})$ (1) (A) but not with the section itself was that the court felt obliged to get without the ambit of the proviso before finding an 8 (b) (3) violation.

97286 F.2d 442 (7th Cir. 1961).

98 Id. at 445 . 
tention of membership . . . ." We assume that a union has broad powers in prescribing rules relative to the acquisition and retention of its members. However, that power, in our view, is not absolute. It goes beyond any permissible limit when it imposes a sanction upon a member because of his exercise of a right guaranteed by the Act. Coercive action, whether by way of fine, discharge or otherwise, which deprives a member of his right to work and his employer of the benefit of his services, cannot be said to relate only to the internal affairs of the union. ${ }^{99}$

It can thus be seen that this case contains very strong language to the effect that court-enforceable union fines are violative of section 8 (b) (1) (A). However, the above language also seems broad enough completely to nullify the proviso. If by "discharge or otherwise" the court meant to include expulsion or suspension from membership, this dictum is clearly wrong. If the proviso covers any union rules, it covers these. To argue that the proviso becomes inapplicable whenever the union's action coerces the member in the exercise of section 7 rights is absurd, for the proviso becomes applicable only when the union conduct comes within section $8(\mathrm{~b})(1)(A)$. Since the proviso was certainly intended to have some application, as earlier Seventh Circuit cases hold, ${ }^{100}$ it seems that the above dictum should not be read so as to exclude expulsion or suspension from membership from the proviso's protection. ${ }^{101}$

Related to the problem whether union fining is a mandatory bargaining subject is the question of a union's right to obtain the

99 Id. at 446. Once again, as in Associated Home Builders, the court had to escape the proviso in order to find that fines were a mandatory bargaining subject.

100 In American Newspaper Publishers Ass'n v. NLRB, 193 F.2d 782, 800 (7th Cir. 1951), aff'd on other grominds, 345 U.S. 100 (1953), the court upheld the right of a union to expel its members :

Under this limitation [the proviso] Congress left labor organizations free to adopt any rules they desired governing membership in their organizations. Members could be expelled for any reason and in any manner prescribed by the organization's rules, so far as $\$ 8(\mathrm{~b})(1)(\mathrm{A})$ is concerned.

In the later case of NLRB v. Local 286, UAW, 222 F.2d 95 (7th Cir. 1955), the court reversed the Board's finding of an $\$ 8(\mathrm{~b})(1)$ (A) violation where the union had removed the union insurance coverage of several members who refused to pay fines levied against them. Finding that the insurance coverage was "a benefit incidental to union membership," the court stated: "Its threatened withdrawal of the rights of the complaining employees, as a disciplinary measure, was in full conformity with respondent's right to regulate its internal affairs" (citing American Nezspaper Publishers Ass'n). Id. at 98.

101 There is also a serious analytical problem with the broad holding in this case that the clause limiting the union's right to fine was a mandatory bargaining subject. If this were a mandatory subject, then it would have been permissible for the union to insist to an impasse upon refusing to incorporate it into the agreement. But, if it is a violation of the act for the union so to discipline its members, it then seems that the union cannot, "in good faith," so insist. Nevertheless, if the case is limited to its factual holding-that the employer may insist to an impasse upon the clauseit does not seem objectionable. 
employer's help, through the collective bargaining agreement, in disciplining its members. Since this would be employer discrimination which encourages membership in the union, sections 8 (a)(3) and 8 (b) (2) seem to answer this question in the negative. ${ }^{102}$ A case so holding is NLRB v. Bell Aircraft Corp. ${ }^{103}$ In that case the collective bargaining agreement stated that there should be no promotion of employees against whom union charges were pending. Charges were pending against several union members who had returned to work during a strike. After arbitration the employer agreed to abide by the agreement and did not promote the employees. The Board found not only $8(\mathrm{a})(3)$ and $8(\mathrm{~b})(2)$ violations but also $8(\mathrm{a})(1)$ and 8(b) (1) (A) infractions. The Second Circuit affirmed:

Section 7 gave Finch the right to take part in the strike or not as he pleased, and if he chose not to take part in the strike it was an unfair labor practice for either the employer or the union to interfere with the exercise of that right. Section $8(a)(1)$ and (b) (1) (A)..$^{104}$

Here, then, is a direct holding that section $8(\mathrm{~b})(1)(\mathrm{A})$ protects a union member in exercising his right not to strike.

\section{The Desirability of the Conclusion}

A survey of related cases has revealed not only that the decisions are compatible with the conclusion reached here but also that some of them, e.g., Borden and Bell Aircraft, seem to demand this result and that Allen Bradley, although probably going too far, is imminently close to a holding that court-enforceable union fines are violations of section $8(\mathrm{~b})(1)$ (A). It is now necessary to discern whether this conclusion will have a deleterious or crippling effect upon labor organizations.

One argument to the effect that Congress did not intend to prohibit court-enforceable union fines in 1947 is based on the premise that unions have always fined their members; Congress knew this and yet did not address itself specifically to the problem. While it is undoubtedly true that unions in the past have fined their members and continue to do so, it is not at all clear that court-enforceable fines were or are a prevalent form of union discipline. Indeed, when unions have attempted to use this weapon, they have been promptly challenged. ${ }^{105}$

102 See note 18 supra.

103206 F.2d 235 (2d Cir. 1953).

$104 I d$. at 237.

105 The court-enforced fines which formed the background of the Allen Bradley case were challenged by an 8 (b) (1) (A) charge which was dismissed by the Regional Director; the dismissal was upheld by the General Counsel. Allen Bradley Co. v. NLRB, 286 F.2d 442, 443 (7th Cir. 1961). For other challenges of court-enforced fines, see Local 248, UAW, 149 N.L.R.B. 67 (1964), aff'd sub nom. Allis-Chalmers 
In 1963, the Bureau of Labor Statistics made a study of disciplinary powers and procedures in union constitutions. This study seems to indicate that fines are much less frequently used than suspension and expulsion. ${ }^{106}$

The relative effectiveness of suspension or expulsion as compared with court-enforceable fines depends on the strength and competence of the union involved. If the union furnishes pension and mortuary benefits ${ }^{107}$ or hospitalization coverage ${ }^{108}$ to its members, expulsion is a powerful weapon. If, on the other hand, the union is weak, expulsion will damage the union more than the recalcitrant member. If effectiveness of the unionization process were the only criterion, it would seem that only weak unions should have the power to use court-enforceable fines to compel their members to join in union activities, since the weak union cannot use expulsion as an effective tool. However, Congress, in 1947, thought that compulsory unionism was another relevant consideration in determining appropriate union power. It has already been pointed out that court-enforceable fines under a union shop contract are antithetical to the objectives of the union shop sections of the act. ${ }^{109}$ Therefore, where a weak union is operating under a union shop contract, the policy question whether it should be allowed to use court-enforceable fines boils down to the relative merits of strengthening weak unions vis-à-vis protecting employees from the leverage which a union can exert under compulsory unionism. The current debate over repeal of section $14(\mathrm{~b}){ }^{\mathbf{1 1 0}}$ of the act demonstrates that the policy question is not an easy one-but can there be any doubt of Congress' verdict in 1947 ?

The question left unanswered in the preceding paragraph is whether there is any valid objection, on policy grounds, to permitting a union-at least a weak union-to use the court-enforceable fine under a truly open shop. Hypothesizing complete freedom of choice in joining a union, an analogy to other voluntary associations could be drawn, and there would seem to be no substantial objection to holding that

Mfg. Co. v. NLRB, No. 14853, 7th Cir., Sept. 13, 1965, rev'd on rehearing, 358 F.2d

656 (7th Cir. 1966), cert. granted, 35 U.S.L. WEEK 3110 (U.S. Oct. 10, 1966) (No.

216); Local 283, UAW (Wisconsin Motor Corp.), 145 N.L.R.B. 1097 (1964), appeal

docketed sub nom. Scofield v. NLRB, No. 14698, 7th Cir., June 28, 1964.

108 U.S. Bureau of Labor Statistics, Dep't of Labor, Bull. No. 1350, Disct-

plinary Powers and Procedures in Union Constitutions 17, Table II-7 (1963).

107 Such benefits were provided by the union in American Newspaper Publishers

Ass'n v. NLRB, 193 F.2d 782, 800 (7th Cir. 1951).

108 Hospitalization coverage was provided by the union in NLRB v. Local 286,

UAW, 222 F.2d 95 (7th Cir. 1955).

109 See text accompanying notes 55-60 supra.

110 Section $14(\mathrm{~b})$ provides :

Nothing in this Act shall be construed as authorizing the execution or application of agreements requiring membership in a labor organization as a condition of employment in any State or Territory in which such execution or application is prohibited by State or Territorial law.

61 Stat. 151 (1947), 29 U.S.C. § 164(b) (1964). 
the employee, upon joining a union, assumes all of the burdens as well as the benefits of membership. Of course, this choice can never be absolutely free: since the union is the employee's statutory bargaining representative whether he joins or not, he forfeits his right to participate in mapping his destiny as an employee by deciding not to join. However, the choice is probably free enough to convince many that where there is an open union, the employee should be held to waive his section 7 rights and assume all the burdens of union membership along with the privileges. An even more convincing argument is that under an open shop the employee should at least be allowed effectively to waive his section 7 rights if he explicitly does so upon joining the union. These arguments have a great deal of merit on policy grounds. The difficult questions are whether a line can be drawn which is consistent with congressional intent, and, if so, whether this line should be drawn between union shops and open shops or between waiver de jure and waiver de facto.

\section{The Current Litigation}

The above discussion has revealed that, at least in a union shop situation, the conclusion that court-enforceable union fines are proscribed under section $8(\mathrm{~b})(1)(\mathrm{A})$ is defensible on policy groundsspecifically, the congressional policy of limiting compulsory unionism to financial support. As the compulsory aspect of union membership weakens, so do the policy arguments behind the above interpretation of section 8(b)(1)(A); and, correspondingly, the probability increases that the Board and the courts will seek to separate the particular fine from the scope of the section. It remains to be seen how the Board and the courts have actually been treating the problem. The position of the Board now seems relatively clear: court-enforceable union fines do not violate section 8 (b) (1) (A). Its authority for this interpretation dates back to the 1954 Board decision in Minneapolis Star \& Tribune Co.: ${ }^{111}$

We find, in agreement with the Trial Examiner, that the imposition of a $\$ 500$ fine on Carpenter by the Respondent Union for his failure to engage in certain of its activities is not violative of Section $8(\mathrm{~b})(1)(\mathrm{A})$ of the Act. It is well established that the proviso to Section 8(b)(1)(A) precludes any such interference with the internal affairs of a labor organization..$^{112}$

111109 N.L.R.B. 727 (1954).

112 Id. at 729. As authority for this proposition, the Board cited its decision in American Newspaper Publishers Ass'n v. NLRB, 86 N.L.R.B. 951 (1949), where the alleged violation of $\S 8(\mathrm{~b})(1)(\mathrm{A})$ was expulsion from membership rather than union fines. 
The conduct for which the petitioner was sought to be punished was his failure to attend union meetings or perform picket duty. The collective bargaining agreement required union membership. There is no statement either in the trial examiner's intermediate report or in the Board's opinion as to whether the union sought court enforcement of this fine. A conclusion that the union was powerful enough to collect the fine without resort to the courts seems justified in light of the trial examiner's statement that punishment was originally loss of employment and was later reduced to the fine plus suspension from work. ${ }^{113}$

It was not until 1964 that this issue again came before the Board. ${ }^{114}$ The first of the recent cases to be heard by the Board was Local 283, UAW (Wisconsin Motor Corp.), ${ }^{115}$ which involved a union rule, in effect for twenty-five years, setting production ceilings on piecework. The company did not consider itself bound by this rule but had, in the past, bargained over it. The collective bargaining agreement contained a union security clause whereby employees could pay the union a "service fee" in lieu of membership. Certain union members were fined for exceeding the ceilings, and court actions were commenced to compel payment. In finding no $8(\mathrm{~b})(1)(\mathrm{A})$ violation, ${ }^{116}$ the majority of the Board described the union's disciplinary measures as internal union affairs and relied heavily upon a congressional intent not to regulate these affairs under section 8(b)(1) (A). The Board arrived at its decision without the aid of the proviso: "Section 8(b) (1) (A) was not intended to reach the conduct here involved, even without regard to the purpose of the proviso, because, as is pointed out, it was not the kind of activity with which Section $8(\mathrm{~b})(1)(\mathrm{A})$ was concerned." 117 However, the Board did state that

113 When Carpenter returned to work, he was dropped to the bottom of the seniority list with the result that his income was reduced. The Board held that this drop in seniority and the suspension from work zere violations of $\S 8(\mathrm{~b})(1)(\mathrm{A})$ as well as $\$ 8($ b) (2). 109 N.L.R.B. at 728-29.

114 The dismissal of the union fine charge which preceded the Allerz Bradley case is discussed in note 105 supra.

115145 N.L.R.B. 1097 (1964), appeal docketed sub nom. Scofield v. NLRB, No. 14698, 7th Cir., June 28, 1964.

116 The Board refused to accept the General Counsel's attempted distinction of Minneapolis Star: "We do not agree with the General Counsel that there is an implication in the Board's decision in that case that the imposition of the fine was collectible only by threat of expulsion." Id. at 1103 n.12. However, the trial examiner, although reaching the same result as the Board, seems to have agreed with the General Counsel's interpretation of this earlier case:

I had assumed that the Government's theory of liability was based, as in such case it would have had to be, solely on the single factual variance of this case from Minneapolis Star, namely that the union here did not assess the fine as an added condition of membership under penalty of expulsion if not paid, but as a debt asserted as collectible without regard to retention of membership ...

Id. at 1114 .

$117 \mathrm{Id}$. at 1101. The Board based this conclusion on that portion of the legislative history indicating a desire not to interfere with "internal union affairs" and a concern only with organizing tactics of unions. 
the effect of the proviso should not be limited to fines collectible only through threat of expulsion. The fact that membership was not compulsory was evidently important to the decision: "The Charging Parties are all members of the Union, who, by their decision to join, have elected to subject themselves commonly with other union members to union regulation and discipline." 118 In the course of the opinion, the Board found it necessary to repudiate the Seventh Circuit's Allen Bradley decision, stating that it was in conflict with an earlier Seventh Circuit case. Member Leedom filed a strong dissent:

[T] he economic pressure inherent in a fine is not unlike the pressure caused by the threat of loss of employment which has always been recognized as economic "intimidation" or "reprisal" constituting a violation . . . . In my opinion, there is little difference between a union's causing the discharge of an employee for refraining from engaging in concerted activity, and a union's fining an employee the partial, or total, equivalent of his salary .... ${ }^{119}$

Although $W$ isconsin Motor was the first of the recent union fine cases to be passed on by the Board, it has been delayed by a procedural issue which took it to the Supreme Court; ${ }^{120}$ it is now pending before the Seventh Circuit for a hearing on the merits.

The next case to reach the Board was Associated Home Builders, ${ }^{121}$ which also involved fines for exceeding production standards, but there the union had applied union dues to payment of the fines instead of using court proceedings. Since the union was operating under a strict union shop contract, ${ }^{122}$ this disciplinary measure seriously impaired the job status of the fined members. If they failed to pay extra dues, they could lose their jobs. The Board accordingly found that the application of dues payments to fines was an 8(b) (1) (A) violation, and this determination was not contested upon appeal. However, the Board relied on Wisconsin Motor in holding that the fines, standing apart from application of dues, did not violate the section. The Ninth Circuit's avoidance of this issue

118 Id. at 1099.

$119 \mathrm{Id}$. at 1107 n.24.

120 Local 283, UAW v. Scofield, 382 U.S. 205 (1965). The Seventh Circuit denied the union's motion to intervene upon appeal, authorizing it to file a brief amicus curiae without leave to participate in oral argument. The Supreme Court reversed, allowing intervention.

121 Associated Home Builders of the Greater East Bay. Inc. v. NLRB, 352 F.2d 745 (9th Cir. 1965).

122 Brief for Appellant, App., p. 3, Associated Home Builders of the Greater East Bay, Inc. v. NLRB, 352 F.2d 745 (9th Cir. 1965). 
upon appeal is discussed above. ${ }^{123}$ Whether the court would have been less reluctant to decide the issue had the union attempted to collect the fines through court proceedings must remain a matter of speculation.

In its next two decisions, the Board proceeded to muddy the waters by holding certain union fines violative of section $8(\mathrm{~b})(1)(\mathrm{A})$. In Local 138, Int'l Union of Operating Eng'rs, ${ }^{124}$ a union member was fined for filing an unfair labor practice charge with the Board before exhausting his internal union remedies. Although, as in Associated Home Builders, the fine was tied to union dues, the Board did not rest on this narrow ground:

There can be no doubt that a fine is by nature coercive, and that the imposition of a fine by a labor organization upon a member who files charges with the Board does restrain and coerce that member in the exercise of his right to file charges. The union's conduct is no less coercive where the filing of the charges is alleged to be in conflict with an internal union rule or policy and the fine is imposed allegedly to enforce that internal policy. Thus, we find that the fine imposed upon Skura herein is in clear conflict with Section 8 (b) (1) (A) . . . unless immunized by the proviso . . . or some other Federal policy. ${ }^{125}$

The Board, finding no such limitation, distinguished the Wisconsin Motor decision as follows:

There, unlike the instant case, the Board was dealing with a union rule which in the circumstances of that case did not run counter to other recognized public policies and, therefore, was not beyond the competence of the union to adopt and enforce. . . By the rule under consideration here, however, Respondent attempted to regulate its members' access to the Board's processes. Considering the overriding public interest involved, it is our opinion that no private organization should be permitted to prevent or regulate access to the Board ..... ${ }^{126}$

The fact situation in Local 138 involved an important LandrumGriffin Act problem, ${ }^{127}$ and it was not long before its companion case,

123 See text accompanying notes 94-95 supra.

124148 N.L.R.B. 679 (1964).

$125 \mathrm{Id}$. at 682 . (Footnote omitted.)

126 Ibid.

127 Section 101(a) (4) of the Labor-Management Reporting and Disclosure Act of 1959 provides, inter alia, that a union may not limit the right of a member to institute an action before the Board, but with the proviso that "any such member may be required to exhaust reasonable hearing procedures (but not to exceed a 
H. B. Roberts, ${ }^{128}$ reached the D. C. Circuit. Roberts involved the same fact situation as Local 138 and was decided in the same way by the Board. The court upheld the Board's finding of an 8(b)(1)(A) violation: "That a fine such as here imposed is restraint or coercion in the ordinary meaning of those terms is clear." 129 However, in seeming accord with the Board's distinguishing of Wisconsin Motor in Local 138, the court limited its holding as follows:

We limit our approval of the Board's construction of its powers to the case before us, where the fine was not imposed because of the member's harassing conduct as a member, but, as the case is presented to us, simply because he filed the charges or did so without pursuing possible internal remedies. ${ }^{130}$

four-month lapse of time) within such organization, before instituting legal or administrative proceedings against such organizations... ." 73 Stat. 522 (1959), 29 U.S.C. $\$ 411$ (a) (4) (1964). In deciding a companion case to Local 138, the D.C. Circuit explained the inapplicability of $\S 101(\mathrm{a})(4)$ to $\S 8(\mathrm{~b})(1)(\mathrm{A})$ violations as follows:

This statute, speaking roughly, parallels rather than meshes into the preexisting Acts insofar at least as the latter proscribe unfair labor practices of either employers or labor organizations. Thus considered it would seem that Section 101 (a) (4) has little bearing one way or the other upon the right of the Board by its traditional methods to preclude coercion upon one seeking its protection ... This fortifies our agreement with the Board that the proviso to Section 101(a) (4) does not legalize a coercive fine imposed upon a member by a labor organization for his failure to exhaust internal remedies for four months before filing an unfair labor practice charge against his union. The proviso does authorize, indeed it may require, the agency or court to which the member comes for relief to withhold the exercise of its authority - for four months if reasonable internal procedures are available and are not earlier exhausted ....

Roberts v. NLRB, 350 F.2d 427, 430 (D.C. Cir. 1965).

128148 N.L.R.B. 674 (1964), aff'd, 350 F.2d 427 (D.C. Cir. 1965).

129 Roberts v. NLRB, 350 F.2d 427, 428 (D.C. Cir. 1965).

130 Id. at 430 . There have subsequently been several other Board decisions involving union fines for initiating proceedings before the Board. Local 238, Wood, Wire \& Metal Lathers' Int1 Union, 156 N.L.R.B. No. 93, 61 L.R.R.M. 1172 (1966), held, in accord with Local 138 and Roberts, that a fine imposed for filing unfair labor practice charges with the Board was an 8(b)(1)(A) violation. To the same effect is the decision in Houston Typographical Union, 158 N.L.R.B. No. 104, 62 L.R.R.M. 1174 (1966), where the union imposed the fine in order to defray expenses incurred in defending the unfair labor practice charges.

Two 1965 Board decisions, although involving expulsion and suspension rather than fines, attempt to distinguish the Local 138 result from cases of union discipline for filing decertification petitions with the Board. In Tawas Tube Prods., Inc., 151 N.L.R.B. No. 9, 58 L.R.R.M. 1330 (1965), the union expelled members for filing and supporting a decertification petition. The Board held that this did not interfere with the employees' freedom of choice so as to warrant setting aside the results of a representation election, distinguishing the case from Local 138 as follows:

This case, however, presents a situation where union members have resorted to the Board for the purpose of attacking the very existence of their union rather than as an effort to compel it to abide by the Act. We do not consider it beyond the competence of the Union to protect itself in this situation by the application of reasonable membership rules and discipline. Furthermore, the employees' attempt to repudiate the Union by a decertification proceeding demonstrates that loss of membership was of no significance to them; consequently their expulsion from the Union could hardly be an effective deterrent against resorting to the Board. 
In its next decision, Local $248, U A W{ }^{131}$ the Board reaffirmed the position that fines imposed for filing unfair labor practice charges are an exception to the rule that fines are internal union affairs and thus not within the scope of section 8(b) (1) (A). They are an exception because the rules imposing such fines are "beyond the competence of the union to enforce since they interfered with the right of union members to seek redress with the Board through the filing of charges." 132 In this manner, the Board distinguished Local 138 and Roberts and held that court-enforced fines imposed upon members of a union shop for refusal to participate in an economic strike did not violate section $8(\mathrm{~b})(1)(\mathrm{A})$. After discussing Wisconsin Motor, the Board stated:

Here, too, the Respondents have properly maintained the distinction between treatment of the individual as a member of the Union and treatment of him as an employee. They have imposed the fine only on their own members. It is not alleged that the Respondents ever attempted to affect the jobs or working conditions of any of the fined individuals. Nor is it alleged that the rule prohibiting members from crossing a picket line during a strike is not the legitimate concern of a union or properly the subject matter of internal discipline. It may be said then that the Respondents were engaged only in prescribing and enforcing their own rules with respect to the acquisition or retention of membership. ${ }^{133}$

Member Leedom again dissented:

Yet, my colleagues of the majority revert again to the reasoning of the Wisconsin Motor case and find no violation because, in their view, the fined individuals are affected only in their status as members and not as employees. I think it will come as a surprise to the affected individual when he is told that a union fine designed to induce him to respect picket lines and stay away from his job does not touch him as an

58 L.R.R.M. at 1331. In Local 4028, United Steelworkers, 154 N.L.R.B. No. 54, 60 L.R.R.M. 1008 (1965), the Board held that the union was protected by the proviso to $\$ 8(\mathrm{~b})(1)(\mathrm{A})$ in suspending a member for filing a decertification petition with the Board, following Tazeas. The Board stated that in Tawas

the Board took note of the fundamental distinction between union disciplinary action aimed at the filing of charges seeking redress for asserted infringement of statutory rights, as in Skura [Local 138], and union disciplinary action aimed at defending itself from conduct which seeks to undermine its very existence.

60 L.R.R.M. at 1009.

131149 N.L.R.B. 67 (1964), aff'd sub tom. Allis-Chalmers Mfg. Co. v. NLRB, No. 14853, 7th Cir., Sept. 13, 1965, rev'd on rehearing, 358 F.2d 656 (7th Cir. 1966), cert. granted, 35 U'.S.L. WEER 3110 (U.S. Oct. 10, 1966) (No. 216).

Term; renumbered No. 216, 1966 Term).

132 Id. at 69.

133 Ibid. 
employee, but only as a union member. . . . By their decision here, as well as their decision in Wisconsin Motor, my colleagues seem to say that some protected activities are not protected from the coercion of a union fine. I see no warrant for distinguishing in this respect between various kinds of protected activities . . . ${ }^{134}$

In September, 1965, a three-judge panel of the Seventh Circuit handed down a decision in this case in Allis-Chalmers Mfg. Co. $v$. $N L R B .^{135}$ This opinion was the first court of appeals decision directly confronting the lawfulness of court-enforceable union fines (except for Roberts, which the D.C. Circuit limited to its particular facts), and it represented a definite victory for the Board:

When Congress was considering the 1947 amendments, it was well aware of union disciplinary measures, including fines, for such activities as "strikebreaking." If Congress had intended to prohibit such fines-while at the same time permitting expulsion as a disciplinary measure-the intention to do so could be expected to be clear. . . . The indications, however, are to the contrary. ${ }^{136}$

The court analyzed the legislative history and decided that section 8 (b) (1) was directed against "the specific evils of force, violence, and threats thereof, mass picketing, and economic reprisal in the form of inducing an employer to discriminate against an employee in his job rights" and was not intended to cover "fines collectible by legal process, which may be described as "coercive." "137 The opinion is replete with policy arguments:

It would be difficult to accept the proposition that a union should be the one secular society in our nation which one may enter without being bound by majority rule and without submission to some limitations on rights for the common good. Upon entering, union members must take not only the benefits but the burdens also . . . and these burdens are not solely financial. Implicit in the Section 7 right to organize is the duty, once that right has been exercised, to support the organization. ${ }^{138}$

The court stated that its earlier decision in Allen Bradley was not controlling:

$134 I d$. at 73.

135 No. 14853, 7th Cir., Sept. 13, 1965.

136 Id. at 4.

137 Id. at 5 .

$138 I d$. at 8. 
We do not see how, if fining a union member for crossing a picket line is unlawful coercion, as Allis-Chalmers claims here, it can be a matter for collective bargaining. Nor can we see how, if the employer is "concerned" with a union's fining its members for crossing picket lines, so as to give the employer a bargainable interest in the matter-one of the principal bases of the Allen Bradley decision-it can be less "concerned" over the expulsion of members, which the employer here concedes is lawful. ${ }^{139}$

The Seventh Circuit granted Allis-Chalmers' petition for a rehearing en banc and in March, 1966, by a vote of four to three, the court reversed itself and found an $8(\mathrm{~b})(1)$ (A) violation. ${ }^{140}$ Two judges from the original panel had, between September and March, changed their minds; and one of them, Judge Knoch, wrote the majority opinion on rehearing. The court again partially relied on policy arguments-ones cutting the other way. ${ }^{141}$ The majority stated that the original decision did conflict with the holding in Allen Bradley and explained away any internal inconsistency in that case with the assertion that "activity already prohibited by statute is not by virtue of that fact alone barred from further prohibition by a provision in a contract." ${ }^{142}$ The primary basis upon which the decision rested was that the words of the statute clearly outlaw the fines in question, and there is therefore no need to resort to legislative history. ${ }^{143}$ Further, the court stated that the Taft-Hartley legislative history as a whole is in accord with this reading of the statute. ${ }^{144}$ The court was undoubtedly impressed by the fact that the case involved a union shop:

The expressed Congressional policy protecting the union member is particularly apt where, as in the case before us, membership is the result not of individual voluntary choice but of the insertion of a union security provision in the contract under which a substantial minority of the employees may have been forced into membership. ${ }^{145}$

There were three separate dissenting opinions, each centering on the issue of voluntary union membership. Judge Kiley (who wrote the three-judge panel opinion) insisted that the issue of forced membership was not before the court:

139 Id. at 9.

140 Allis-Chalmers Mfg. Co. v. NLRB, 358 F.2d 656 (7th Cir. 1966).

141 Id. at 660 .

142 Id. at 661. See note 101 supra.

$143 I d$. at 660 .

$144 I d$. at 661 .

$145 I d$. at 660. (Emphasis added.) 
An argument was introduced by Allis-Chalmers in its rehearing petition that the men before us were involuntary members having "solely a dues paying status," a "very limited technical" membership. The union's answer to the petition stated that the union shop clause does not require full union membership; that the union could not compel employees to take the union oath, submitting to the union constitution and rule. The union's answer conceded that if the men before us had no obligation to the union beyond paying dues and fees, they would not be subject to the union "requirement of obedience to the common cause." In reply Allis-Chalmers shifted gears: "This avoids the question in issue. The question is whether a union may coerce an employee who is a member, be he one voluntarily or involuntarily. It is the Petitioner's position that unions have no such right." The question of involuntariness was not and is not in the case..$^{146}$

Regardless of whether the issue was before the court, all three dissenters maintain that the fined employees were "voluntary" union members who could have protected themselves from internal union discipline if they had "either rejected full union membership or resigned from the union." 147

\section{Concluston}

It seems that Allis-Chalmers-the most authoritative pronouncement on union fines to date-states the correct result but gives the wrong reasons. The dissenters to the en banc opinion were quick to point out the obvious error of refusing to consider the legislative

$146 I d$ at 669 . (Italics in original; footnotes omitted.)

147 Id. at 671 .

A final case shedding some light on $\S 8($ b) (1) (A) as it relates to union fines is Leeds \& Northrup Co. v. NLRB, 357 F.2d 527 (3d Cir. 1966), which held that it was error for the Regional Director and General Counsel of the Board to refuse the charging employer an evidentiary hearing on its objections to an informal settlement agreement executed between the Regional Director and the union. The union activities inducing the charges included the imposition of fines for refusal to participate in a strike. The fines equalled the wages earned during the strike, and the union instituted civil actions to collect them. Necessarily by way of dictum, the Third Circuit stated:

In some instances, as where only the status of the employee as a member of the union is affected, union fines standing alone may not violate the Act [citing Wisconsin Motor Corp. and the original Seventh Circuit decision in Allis-Chalmers]. But to equate union fines with total wages earned by a non-striking employee is the grossest form of economic coercion affecting not only union membership status but also the relationship between the employee and his employer in violation of the Act. Such economic coercion is calculated in design and effect to force an employee to act in concert with the union in future labor-management strife. Congress has imposed strict limitation on compulsory unionism, and the Supreme Court has determined the obligation of union membership to be confined solely to the payment of dues.

Id. at 536 . 
history. ${ }^{148}$ However, as has been demonstrated, ${ }^{149}$ the legislative history of section $8(\mathrm{~b})(1)$ (A) demands the result reached by the court. While there may be room for judicial departure from what seems to be an absolute prohibition upon court-enforceable union fines, ${ }^{150}$ Allis-Chalmers, involving a union shop, was hardly an appropriate case for such a departure. The unsoundness of holding an employee under a union shop contract responsible for affirmatively limiting his membership to dues-paying status has already been discussed..$^{151}$ It therefore seems that, at least under a union shop clause, a union member should not be held as a matter of law to have waived his section 7 rights. When a case arises where the fined union member can be said to have made what was, in reality, a voluntary decision to avail himself of the privileges of full membership in the union, then, and only then, should a court begin to consider the creation of a judicial exception to what seems to be a clear legislative pronouncement that a union may not coerce an employee in the exercise of his section 7 rights by means of a court-enforceable fine.

Although the Board has not yet been willing to accept the full force of this pronouncement in section $8(\mathrm{~b})(1)$ (A) proceedings, complete acceptance of the principle which it put forward in Local 138 and Roberts should lead it to acquiescence in the Allis-Chalmers result. Granting that the unfettered right to file charges with the Board may be essential to the Board's effective administration of national labor legislation, it is difficult to understand why this right is a more important section 7 right ${ }^{152}$ than the right to refrain from concerted union activities. Unless a better distinction than that interference with the right to file charges "run[s] counter to other recognized public policies" ${ }^{153}$ can be given, the Board's limitation on this 8 (b)(1) (A) prohibition should fall, and the Board should reconsider the results it reached in cases such as Minneapolis Star \& Tribune Co. and Wisconsin Motor Corp.

148358 F.2d at 671.

149 Section III supra.

150 Section VII supra.

151 See text accompanying notes 59-60 supra.

152 In fact, it does not seem that the right to file charges with the Board is a $\$ 7$ right at all.

153 Note 126 supra and accompanying text. 